\title{
Sam, un perro anciano
}

Keywords: abandono; derecho; legislación; animal

Hace unos días me llegó un correo electrónico, en el que una buena amiga, Catedrática de Filología, que dedica parte de su escaso tiempo libre a trabajar como voluntaria en el CAAC de Barcelona [1] , enviaba una dolorosa noticia.

Se trataba de Sam, un hermoso Samoyedo de 12 años que acababan de encontrar atado a la entrada del CAAC. Las fotos mostraban un perro guapo, limpio, bien cuidado, con una correa y un collar en perfecto estado pero, sobre todo, en las fotos resaltaba la mirada de Sam. Una mirada entre el aturdimiento y la sorpresa; una mirada dulce, sosegada y triste. A Sam, supuestamente, lo dejaron atado a la puerta del Centro de Acogida de Animales sus dueños, a una hora, por la noche o de madrugada, en que nadie pudo verlos, ni tomar el número de la matrícula del coche. Un acto cobarde y cruel.

Si nos preguntamos el por qué de un comportamiento semejante, el por qué del abandono de Sam, sólo se puede encontrar una explicación que es la de que Sam, a los 12 años, con artrosis en sus caderas, cuenta con poco tiempo de vida y los años que le queden requerirán, posiblemente, gastos provenientes precisamente de su edad: pastillas contra el dolor de los huesos, pienso especial para que no gane peso, visitas más frecuentes al veterinario, etc. O quizá sus dueños hayan experimentado cambios en sus vidas o en su economía, que les hayan llevado a adoptar la 'solución' más dolorosa para Sam. Es una posible explicación, en ningún caso una justificación.

Puedo imaginar la vida de Sam antes de verse atado a un lugar desconocido para él; una vida en familia, compartiendo con ojos agradecidos y alegres todo lo que había a su alrededor; quizá desde que era un cachorro blanco, una bola de pelo suave, no había conocido otra realidad; quizá, como muchos de nuestros perros, tenía su cama, un lugar en el sofá, un juguete preferido, una rutina de paseos y hasta algún viaje y, seguro, muchas caricias. Por eso puedo interpretar en la mirada de Sam (que no se va de mi cabeza), el desconcierto primero y la tristeza después. Las horas vacías hasta que lo desataron y lo llevaron al CAAC para examinarlo. Todo distinto. Todo desconocido. Seguro que en el CAAC el personal y los voluntarios se desvivieron por él, pero no estaba en su casa.

¿Cúando volverán mis padres?, se preguntaría, quizá, pues para los perros nosotros somos su "todo”, nos siguen a todas partes, nos miran con admiración, pendientes de nuestros menores gestos, somos su alegría y su seguridad. Pudo imaginarme el sufrimiento de Sam, porque tengo un perro que ahora tiene ya quince años y medio (gloria bendita!!) y cada día, aunque conserva toda su gracia, es un poco menos autónomo.

¿Qué le debemos a un perro que ha compartido más de una década con nosotros?. No sé si la palabra deber es la adecuada, pero lo que quiero expresar está muy claro. Una vida de entrega absoluta, de lealtad sin fisuras, de alegría permanente, de saber estar y de saber amar, no puede tener como final el abandono. Un perro viejo, es un perro tan frágil y dependiente como un cachorro lleno de gracia. Es fácil querer a un cachorro, pues más fácil es, tiene que ser, querer a un perro anciano. Nos necesita y hay que ofrecerle un cariño incondicional y una vida fácil y digna.

En España el abandono no está castigado. Está castigado el abandono que pone en peligro la vida o la integridad física del animal [2]. Es un matiz jurídico por el que se justifican muchas conductas deleznables, pero, como dijo un juez en una sentencia ejemplar, abandonar a un perro equivale -salvando las distancias- a abandonar a un niño que no se puede valer por sí mismo [3]. No es ésa la letra del 
precepto penal, pero sí es la interpretación que debería de dársele y, consecuentemente, que el abandono, puro y simple, fuera objeto de castigo. Así ocurre en países como Alemania, Austria o, recientemente, en Rumanía.

Por lo tanto, el abandono de un perro viejo, que sí pone en peligro la vida y la integridad física del perro, ¿debe o no estar castigado severamente por el Derecho?. A mi modo de ver, la respuesta es afirmativa. Aún no ha llegado a los tribunales una denuncia por abandono de un perro anciano, que haya generado una sanción como corresponde a una conducta injustificable para la norma jurídica. No dudo de que parte del progreso del Derecho en relación con los animales, radica en cubrir el riesgo de abandono simple de un perro, pues la obligación moral y legal de todo propietario de un animal es cuidarlo y asistirlo de manera que se garantice, en todo momento, su vida y su integridad física.

Esto, dicho de forma breve y sintética, es lo que se denomina "tenencia responsable”, durante todos los años (ojalá sean muchos!) de la vida del animal.

LA EDITORA

Teresa Giménez-Candela Catedrática de Derecho Romano

Animal Law Profesor

Universitat Autònoma de Barcelona

[1] Link externo

[2] Art. 631.2 Código Penal castiga a «quienes abandonen a un animal doméstico en condiciones en que pueda peligrar su vida o su integridad». Este tipo penal exige la concurrencia de dos elementos, por una parte el abandono y por otro la puesta en peligro de la vida o integridad por las condiciones del abandono del animal.

[3] SAP,Segovia, 5.3.2007 (sentencia ): 'Por lo tanto, gramaticalmente el abandono puede entenderse tanto desde un punto de vista activo como omisivo, bastando con que la conducta cause desamparo del animal en este caso. Por otra parte y en cuanto a su definición jurídica, si bien en el ámbito de faltas y dada su reciente tipificación no se encuentra una definición jurisprudencial, sí existen y existían en Códigos anteriores figuras típicas de abandono, como era el abandono de familia o de menores. Salvando las diferencias entre personas y animales, ya contempladas en su distinta gravedad y penalidad, la acción de abandonar sería la misma. Y en cuanto al abandono de menores la doctrina ha sido reiterada en considerar que la conducta típica «consiste en la realización de una conducta, activa u omisiva, provocadora de una situación de desamparo para el menor por el incumplimiento de los deberes de protección establecidos en la normativa aplicable» (STS 4 de octubre de 2001 [ RJ 2001, 8527]). Y esta misma resolución describe también el concepto de desamparo, como concepto normativo del tipo penal, considerando que se refiere a los supuestos en que el niño quede privado de la necesaria asistencia moral o material que incida en su supervivencia o desarrollo.

Trasladando dichos conceptos al ámbito de la falta que ahora enjuiciamos, habrá que entender que el abandono se puede producir tanto porque se deje al animal o porque se le coloque en situación de desamparo, tanto por la acción directa de expulsarle como por la omisiva de no acogerle cuando se sabe dónde se encuentra; puesto que la obligación moral y legal de todo propietario de un animal es cuidar del mismo, y darle la asistencia precisa para permitir su vida e integridad'. 